\title{
Understanding and Grasping the Three Dimensions of New Development Concept
}

\author{
Yuchao Pang \\ School of Marxism, Beijing Jiaotong University, Haidian, Beijing, China \\ *Corresponding author. Email: pyc1004@163.com
}

\begin{abstract}
Firmly implementing the new development concept is the internal requirement of promoting high-quality development and achieving sustainable development at this stage. The proposal of the CPC Central Committee on formulating the 14th five year plan for national economic and social development and the long-term goals for the year 2035 adopted by the Fifth Plenary Session of the 19th Central Committee of the Communist Party of China (hereinafter referred to as the plan and suggestions) stressed that continuously improving the ability and level of implementing the new development concept can provide a solid guarantee for the high-quality growth. A thorough understanding of the practical significance, theoretical connotation and practical path of the new development concept will help us deeply understand and recognize the significance of the new development concept in promoting the development of superior quality and completing the great rejuvenation of the Chinese nation's mission.
\end{abstract}

Keywords: new development concept, sustainable development, practical significance, high quality development

\section{THE PRACTICAL VALUE OF ADHERING TO THE NEW DEVELOPMENT CONCEPT}

"Planning and suggestions" stresses that new development concept of innovation is to meet the people's growing needs for a better life as the fundamental purpose, which clearly expresses the practical goal of the new development concept at the present stage and for a long time in the future: we will adhere to the people-centered value orientation and work hard to realize the people's aspirations for a better life

\subsection{Highlighting the value orientation of taking people as the center}

People centered is the value orientation throughout the new development concept. Xi Jinping stressed that our vision of making development people-centered has been acted on [1]. This is the people's expectation of the Party and the nation, and also the party's and state's commitment to the people. The ultimate goal of the development philosophy that puts people first is to promote the all-round development of people and achieve common prosperity for all, which is also the purport of the new development philosophy.
The people centered development thought reveals the dialectical unity between the people's character and the new development philosophy from the perspective of development and from the overall perspective. The people-centered value orientation is not a cover for theory, but a value to follow in the process of practice. The concept of "people first" is fully reflected in all aspects of development, that is, the original intention of development is to benefit and benefit the people, the development effect is evaluated by the people, and the fruits of development shared by the people. Improving people's livelihood and putting people's interests in the first pursuit of development are important principles upheld by our party and the state. In the new era, we should recognize the regional imbalance in the process of development and transformation, the backward management mode of some industries, the urgent need to adjust and upgrade the development structure, and the ecological cost problems in the development process, which not only hinder the optimization of the economic structure, but also affect the people's life happiness index. Therefore, whether the problems in development are properly solved is the objective standard of development effectiveness, and the subjective standard of development effectiveness is whether people's happiness is directly proportional to level of economic development. 
Therefore, the people have the most say over the effectiveness of development.

\subsection{Theoretical orientation of promoting high quality development}

In this new era and new stage, profound changes in the domestic and international environment have brought new opportunities as well as new challenges. Dangers and opportunities coexist, opportunities arise from dangers, and dangers can also be turned into opportunities. The Party and the state lead the economic work, adhere to the new development concept, and consider the scientific judgment and initiative made according to the development situation at home and abroad from the overall perspective.

As the internal elements of the new development concept are interdependent and interrelated to jointly improve the strength and level of development. Highquality innovation is the first driving force for highquality growth. "Planning and suggestions" emphasizes that innovation should be at the core of China's modernization drive. The party and the state have promoted the role of innovation in development as the "core position" and "strategic support" of development, and emphasized the role of innovation driven in optimizing economic structure and increasing economic strength. Coordination is the inherent requirement of high quality development. China has a population of more than 1.4 billion, and the demand of more than 1.4 billion people is the strategic basis for us to expand the domestic market. The people's growing needs for a better life include not only the pursuit of reasonable rights and interests in environment, education, rule of law, social security, fairness, but also better expectations for the development of economy, politics, culture, society and ecology. Therefore, we should coordinate the coordinated development of all aspects of the "five in one" overall layout, and deepen the benign reform of the supply side and demand side, "make the domestic market the main source of final demand" [2]. It is an objective requirement to expand the domestic market and drive economic development. Green is a necessary condition for high quality development. To promote green development and realize the modernization of symbiosis between man and nature is an important aspect of people's life quality and the basis of sustainable economic development.

It is mentioned in the "planning and recommendations" that improving the overall coordination mechanism in the field of ecological civilization, continuously improving the environmental quality are the inevitable way to realize the unity of economic development and beautification of the environment, and also the necessary demand for the indepth implementation of the sustainable development strategy. Opening up is a necessary way to coordinate development and security and improve the comprehensive national strength. In the era of unprecedented changes in the world in a century, we should continue to expand opening-up and actively carry out cooperation and competition in international investment, trade and technological exchanges in a wider range and at a deeper level. Only in this way can we continuously promote high-level opening-up, and in this process, we will also find the gap with the developed countries and pursue them head-on to promote highquality development. Sharing is a necessary part of high quality development. The people-centered development thought determines that the process of high-quality development is the process of all people's co-construction, and the achievements of high-quality development are the results shared by all the people. Realizing common prosperity is the innate demand of socialism, and it is also the manifestation of the system advantages of socialism with Chinese characteristics.

\subsection{Clear practical direction of solving the main contradiction in Chinese society}

The principal contradiction in Chinese society in the new era has been transformed into the contradiction between the people's ever-increasing needs for a better life and unbalanced and inadequate development, which is not only the theoretical basis for the new development concept, but also the practical basis for implementing the new development concept. Fundamentally speaking, the principal contradiction in our society is the contradiction between demand and supply. Adhering to the new concept of development is conducive to solving the problem of demand as well as supply.

Adheres to the concept of the new development will help to solve the problem of demand. With the realization of building a moderately prosperous society in all respects, people's needs are better quality education, higher level medical care, better social security system, better environment for housing and so on. Compared with before, people's needs also have a higher level, more comprehensive pursuit. To meet the people's needs for a better life is the proper meaning of implementing the new vision on development. Specifically speaking, innovative development is committed to creating more possibilities and better life for the people; coordinated development is committed to creating a better objective environment to meet the diversity of people's needs; green development is committed to continuously improving environmental quality and meeting people's needs for better housing conditions; and shared development is committed to improving the people's livelihood and well-being of all Chinese people, to implement the rights of the people in all aspects.

Adhering to the new development concept will help to solve the imbalance and insufficiency of development. On the one hand, the imbalance of development is quite prominent, mainly manifested in the large gap between 
urban and rural development level, regional coordinated development has not yet been realized, and the mismatch between economic development and various basic security. The solution of these problems is the practical direction of the new development concept. Specifically, innovation is conducive to solving the power problem of unbalanced development; green is conducive to guiding people to respect objective laws, to solve the cost of ecological imbalance in development; coordinated development and shared development are conducive to narrow the gap between the rich and the poor among regions , and promote the overall development of society. On the other hand, insufficient development also restricts the process of socialist modernization. The inadequacy of development is directly reflected in the urgent need to improve innovation ability, improve public infrastructure, low level of industrial system modernization, lack of economic system with core competitiveness, etc. The solution of these problems is the driving force of the new development concept. Innovative development is conducive to promoting the optimization and upgrading of economic structure, changing the thinking mode of enterprise development, transforming the growth momentum, and enhancing the innovation and competitiveness of China's economy; coordinated development and shared development are conducive to improving the construction of public infrastructure. We should ensure that the people feel justice and equality in the modernization of basic public services and open development is conducive to expanding international market. At the same time, the relationship between independence and opening to the outside world should be properly grasped. Standing in a new historical position, striving to achieve a more balanced, full, sustainable and safer development, not only adapts to the transformation of the main social contradictions, but also the internal need to realize the sustainable economic development and socialist modernization.

\section{THE THEORETICAL CONNOTATION OF ADHERING TO THE NEW DEVELOPMENT CONCEPT}

To understand and grasp the connotation of the new development concept, we should not only grasp its constituent elements, but also understand it as a whole. According to the dialectical thinking of system and elements to understand the new development concept, the new development concept is a system, and innovation, coordination, green, open, sharing and other internal elements constitute the internal elements of the system. These internal elements are interdependent, mutually integrated and collaborative support, which provides an integrated thinking for solving the problems in the current development. Therefore, we must grasp the new vision for development as a systematic concept.

\subsection{The theoretical connotation of the new development concept mainly answers the logic questions of who to develop in the new era, what kind of development to achieve and how to develop.}

Specifically, the new development concept is to adhere to develop for the people, and adhere to innovation, coordination, green, open and sharing as the core content. These five development concepts are not only development patterns, but also development approaches. Specifically speaking, the value orientation of adhering to the people as the center has never changed and has been implemented in the development, which is manifested in the goal of the new development concept, which not only pursues high-quality economic development, but also attaches importance to important contents closely related to the immediate interests of the people, such as natural protection, people's livelihood, fairness and justice. The practical way to achieve the goal is also the innovation, coordination, green, open, sharing and other measures proposed from the perspective of the overall interests of the people, which can not only coordinate the overall situation but also achieve sustainable development.

\subsection{As a whole, the new development concept must grasp the internal relations of the internal elements of the whole in order to give full play to its optimal efficiency.}

Xi Jinping said, "the development concepts of innovation, coordination, green, openness and sharing are interconnected and promote each other, and they are a collection with internal links" [3]. Therefore, a thorough understanding of their close relationship is the objective need to understand the connotation of the new concept of development.

It is necessary to observe. As an innovative concept leading development, it is problem-oriented and constrained by realistic conditions. Therefore, to play the leading role of innovation needs a more fair, coordinated and ecological internal environment, as well as expanding opening and expanding the international market. As a harmonious concept to promote healthy and orderly development, it takes respecting the law of development as the premise, and takes the relationship between economy and nature, rich first and rich later, domestic and international as the internal requirements, which proves that it has inherent consistency with green development, shared development and open development. As a green concept for the benefit of future generations, based on respecting the laws of nature, it is committed to infiltrating the green concept into all aspects of economic and social progress and promoting the harmonious coexistence of human and nature. If this is the premise and the benefit and quality of development are 
guaranteed, it is necessary to work together with innovation, coordination, sharing and openness. As an open concept that actively participates in international competition and cooperation, it emphasizes the need for internal and external linkage, makes full use of domestic and foreign markets, and wants to exert influence on the international stage, reform and innovation, coordination, green, sharing and collaborative support, so as to create a solid foundation for opening up and development. As a reflection of the essence of socialism, shared development is a dynamic and comprehensive development. Sharing refers not only to the sharing of economic development achievements, but also to the sharing of politics, society, culture and ecology. At the same time, sharing emphasizes sharing on the premise of co construction. Therefore, the other four development concepts are "co-construction", and what they share are the fruits of "co-construction". Although the five development concepts play different roles in development, they complement each other in function, and jointly promote sustainable and healthy development.

\section{THE PRACTICAL PATH OF ADHERING TO THE NEW DEVELOPMENT CONCEPT}

Promoting a smooth transition from a stage of highspeed growth to a stage of high-quality development is a systematic project. On the basis of a thorough understanding of the "planning and recommendations" and the spirit of the Central Committee, we need to take effective measures under the guidance of the new development philosophy and in close consideration of the realities of various regions and fields, so as to achieve tangible results. At the present stage, we need to adhere to the following aspects.

\subsection{To properly handle the relationship between changing the development mode and developing new industries and promoting the optimization and upgrading of traditional industries.}

Using modern development mode to develop new industries, such as the Internet and artificial intelligence, and implementing the new development concept will not only optimize China's industrial structure, but also greatly improve the industrial competitiveness and development efficiency. In contrast, the production mode of traditional manufacturing industry no longer meets the requirements of the times, and its production efficiency can not keep up with the pace of productivity development. However, its existence time is longer, its volume is larger, and its impact on people's life is greater. If, on the basis of field research and scientific analysis, the transformation and upgrading of traditional industrial structure can be promoted by means of intelligence, refinement and branding, There is still a lot of room for development.
Therefore, the combination of actively developing new industries and promoting the optimization and upgrading of old industries is more conducive to promoting the healthy and sustainable development of economy and society.

\subsection{To deal with the relationship between improving quality and increasing efficiency and supplementing the short board.}

China's socialist contradiction points out that there is a problem of imbalance and insufficiency in the development. This problem has a long history. It is caused by the backwardness of productivity and the long-term pursuit of economic growth rate. In the new stage of development, we will press ahead with reform and development to focus on areas of economic and social weakness. This is the space and potential for high-quality development [4]. Only by analyzing, attaching importance to and solving the weak links of development can we release more development potential and improve the overall level of development. Therefore, it is necessary to facilitate balanced and sufficient development and make up for the short board. Improving quality and efficiency and to supplement the short board are indispensable steps to promote high-quality development.

\section{CONCLUSION}

Adhering to the new development concept is a development concept put forward by the Party and the state in the course of leading economic development that suits China's actual conditions. This development concept will help improve China's economic, scientific and technological strength and overall national strength and promote high-quality development. It will also help to provide other socialist countries with China's development experience and maintain China's image as a responsible major country.

\section{AUTHORS' CONTRIBUTIONS}

The research conception, design, writing, translation, modification and finalization of this article are all completed by myself.

\section{FUND PROJECT}

This paper is one of the periodic achievements of the major project "Research on Xi Jinping's Thought on Governance" (KL115001531) of the Research Center for Theoretical System of Socialism with Chinese Characteristics in Beijing.

\section{REFERENCES}

[1] Xi, J.P. (2017) Decisive Victory in Building a Moderately Prosperous Society in an All-Round 
Way and Achieve the Great Victory of Socialism with Chinese Characteristics for a New Era. People's Daily, 001.

[2] Xi, J.P. (2020) Explanation on the Proposal of the Central Committee of the Communist Party of China on Formulating the Fourteenth Five-Year Plan for National Economic and Social Development and the Vision Goals of 2035. People's Daily, 002.

[3] Xi, J.P. (2016) General Secretary Xi Jinping Series of Important Speeches Readings. Learning Press, Beijing.pp.136.

[4] Zhang, X.L. (2021) High-quality development is qualitative improvement and change. Frontier, 01:30-34. 